\title{
A Study on Employee Motivation in Private School: A Case of Bethany Boarding Higher Secondary School (BHSS) Pokhara
}

Devilal Sharma

\begin{abstract}
S
Managing human resource plays a crucial role in the process of organization's effectiveness. One of the most important functions of HRM is motivation. However, because of complex nature of human behavior, motivation is not easy to understand and use. It is represented by author such as Maslow, McClelland and Herzberg. While some motivation theories try to find out how motivation occurs. Vroom, Adams, Locke and Lantham created the most influential process. The aim of this paper is to find out which motivation factors can effectively increase employee motivation, to know the provided incentives are sufficient or not and the effect of incentives in their performance. This study has suggested that promotion system of the career development is needed to satisfy and motivate the employee. Moreover, the work recognition should create the feeling of they are worth for the organization. The information gained from this paper might be a good starting point for creating motivating systems for existing employees and for new comers. This research was conducted to find out the motivational factors and its effect on employee performance of Bethany Higher Secondary School. Researcher developed a survey questionnaire and distributed to get the view of all the employees. All the responses were analyzed and found that monetary and non-monetary incentives are used to motivate workforce. Good salary and allowances has been used as monetary motivators. While, good working environment, freedom to work and recognition conduct the plan differently and effectively as non-monetary motivator.
\end{abstract}

Key Words: Motivation, incentives, career development, performance, satisfaction, dissatisfaction, workforce, employees, retention, behaviour.

\section{Introduction}

The efficiency of a person depends on two factors, firstly, the level of ability to do a certain work, secondly, the willingness to do the work. So far as the first factor is concerned it can be acquired by education and training, but the second factor can be created by motivation. A person may have several needs and desires. It is only strongly felt needs which become motives. Thus motives are a product of needs and desires. Motives are many and keep on changing with time and are invisible and directed towards certain goals.

Motivation is derived from the word 'motive' which means the latest power in a person which impels him to do a work. Motivation is the process of steering a person's inner drives and actions towards certain goals and committing his energies to achieve these goals. It involve a chain reaction starting with felt needs, resulting in motives which give rise to tension which census action towards goals. It is the process of stimulating people to strive willingly towards the achievement of organizational goals. Motivation may be defined as the work a manager performs in order to induce subordinates to act on the 
desired manner by satisfying their needs and desires. Thus motivation is concerned with how behaviour gets started, is energized, sustained and directed.

Motivation is the act of stimulating someone or oneself to get a desired course of action or to push the right button to get a desired reaction. Motivation is one of the most crucial factors that determine the efficiency and effectiveness of an organization. Motivation is an integral part of management process. An enterprise may have the best of material, machines and other means of production but all these resources are meaningless so long as they are not utilized by properly motivated people.

Managing human resources plays a crucial role in the process of increasing organization's effectiveness. One of the most important functions of HRM is motivation. The importance of motivating people at work is noticeable at all levels of organization. Starting from managers who need to be aware of factors that motivate their subordinates to make them perform well, through employees who need to think through what expectations they have to work, ending up with HR professionals who have to understand motivation to effectively design and implement reward structure and systems. Thus, motivation is an important aspect of HRM. However, because of complex nature of human behaviour, motivation is not easy to understand and to use. Although, some of the research suggested that money is not as important as it seemed to be, many companies tried to implement monetary incentives as their main tool to motivate employees. Performance related pay became the new mantra that was used questionably by plenty of organizations (Frey \& Osterloch, 2002). The literature on a subject of motivation shows that there are several other ways to motivate employees. The most well-known and often cited theories can be divided into two categories: content theories and process theories. The first group is focused on what motivate people. It is represented by authors such as Maslow, McClelland and Herzberg. The second group tries to find out how motivation occurs. Vroom, Adams, Locke and Latham created the most influential process theories. Some authors (Oldman \& Hackman, 2010; Lawyer, 1969) indicate that job design plays important role in shaping employees behaviour while others (Roche \& MacKinnon, 1970; Allender \& Allender, 1998; Mayfield \& Kopf, 1998) suggest that leadership style and freedom given to employees are crucial in motivating employees. Another group of researchers try to prove that recognition can be used to motivate people to perform well. The importance of motivating factors might vary among particular groups of people. However, there are several motivating factors that are very often ranked high positions. Interesting work, full appreciation of work done, feeling of being well informed and involved, and good incentives are the factors that received high rates in many research (Lindahl, 1949; Kovach, 1980, 1987, 1995; Fischer \& Yuan 1998; Kinnear \& Sutherland, 2000).

Performance appraisal is an key factor to motivate employees at work. PA is a systematic and objective way of judging the relative worth or ability of employees in performing their job. PA system is not only an important tool of HRM to develop their employees, but is also used by different companies to reward their employees in form of bonuses, promotions, and pay raise etc. Usage of performance appraisal to reward employees is also used by different theories of motivation like reinforcement theory etc (Talya and Berim, 2010). It was proposed in 2002 by Coens and Jenkins that PA is necessary in organizations to judge, rate and illustrate employee's work attitude or qualities for a specific time period and results are kept confidential by the organization. Lawrel et. al., (1984) discussed that it is current need of the time to keep PA system at the core of integrated HRM activities. Employee motivation, at times, can be an elusive quest for organizations and managers 
due to the multiplicity of incentives that can influence employees to do their best work. Furthermore, short-term financial incentives are often seen as mandatory to foster motivation and are generally viewed very positively by employees in the workplace. However, recent research has indicated that there are other factors that can significantly influence motivation and lead to innovation. Motivation is a basic psychological process. The comprehensive understanding of motivation lies in the need-drive-incentive sequence or cycle. The basic process involves needs (deficiencies), which set drives in motion (deficiencies with direction) accomplish incentives (anything which alleviates a need and reduces a drive). The drives or motives may be classified in many ways. A simple mode of motivation process is given below.

\section{Figure 1: The motivation process}

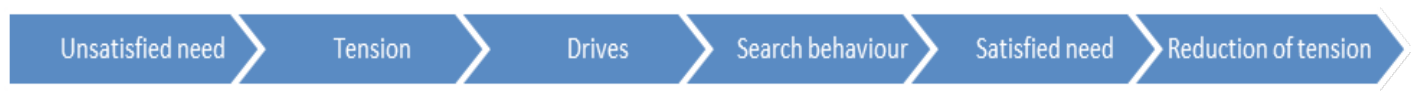

Source: Robbins, 1998 and Chandan, 1997

The most common factors that are taken into consideration come from two categories: monetary and non-monetary incentives. As Armstrong (2007) wrote, money is a motivator because it satisfies a lot of needs. It is a factor which is indispensable for life and which is needed to satisfy basic needs of survival and security. Higher needs such as self-esteem can also be satisfied by it. In other words, money is a symbol of many intangible goals what makes it a powerful motivating factor. Rynes, Gerhart and Minette (2004) in their study on the importance of pay in employee motivation found that money is not a motivating factor for every person and not in every circumstance. However, it is an important factor for most people. That might lead to an underestimation of monetary rewards as one of the motivating factors in job settings.

There is a large group of researchers who neglect the fact that money is a good motivator. For example, McClelland (1968) writes that "money isn't as potent a motivating force as theory and common sense suggest it should be". The result that supports McClelland words come from McKinsey Quarterly recent survey conducted in June 2009 (Dewhurst, Guthridge, \& Mohr, 2009). Responses received from 1,047 executives, managers and employees around the world showed that three non-cash motivators (praise from managers, leadership attention, a chance to lead projects or task forces) are more effective motivators than the three highest-rated financial incentives (cash bonuses, increased base pay, and stock options).

The study concluded that employees who perceive they are involved in decision making, or have a level of control over the job processes are "more satisfied, more motivated and more committed to the organization' than those who perceive lack of control or feel left out in decision making processes of the organization (Perry et al. 2010:508). professors at Massachusetts Institute of Technology and University of California, Santa Barbara, published a paper titled "Incentives and Creativity: Evidence from the Academic Life Sciences" indicating that long term rewards rather than short term rewards helped to motivate scientists in their work and to promote overall greater creativity. The application of this study suggests that short term rewards, that are common in many businesses, may truncate motivation and hinder innovation (Azoulay, Graff-Zivin \& Manso 2010).

Ederer and Manso’s (2011) study titled “Is Pay for Performance Detrimental to Innovation? 
Concluded the optimal incentive scheme that motivates exploration is fundamentally different from standard pay-for-performance schemes used to motivate effort. Tolerance (or even reward) for early failure, reward for long-term success, excessive continuation, commitment to a long-term incentive plan, and timely feedback on performance are all important to motivate exploration. Mullins (2006) suggests that motivation is one of the key ingredients in employee performance and productivity. Even when people have clear work objectives, the right skills and a supportive work environment, they would not get the job done without sufficient motivation to achieve those work objectives. In a study, the authors aimed at examining 'whether monetary rewards can reduce failures to act on cued task goal' (Veling \& Arts, 2010). With a research sample comprising of 36 undergraduates, the authors experimented to see how quick their respondents reacted to specific tasks when given a range of monetary rewards ranging from low to high rewards. The studies found out that giving relatively high monetary rewards, led to 'overall faster responses' to the specific tasks given to respondents. The authors noted that respondents overall fast response to task was positively correlated to the high rewards given. Conversely, the authors also noted that when rewards were on the low side, respondents either slacked or showed little in the task at hand. Their finding is consistent with other studies which noted that relatively high monetary rewards may function as a catalyst for enhanced effort or determination by employees to perform well (Bijleveld et al. 2009, Locke and Braver 2008, Waugh and Gotlib2008).

(Dewhurst, Guthridge and Mohr, 2009) Responses received from 1,047 executives, managers and employees around the world showed that three non-cash motivators (praise from managers, leadership attention, a chance to lead projects or task forces) are more effective motivators than the three highest-rated financial incentives (cash bonuses, increased base pay, and stock options). The study on health workers motivation which was not related to business environment also showed that non-financial motivators play important role in employees' motivation (Mathauer and Imhoff, 2006). Performance appraisal system is not only an important tool of HRM to develop their employees, but is also used by different companies to reward their employees in form of bonuses, promotions, and pay raise etc. Usage of performance appraisal to reward employees is also used by different theories of motivation like reinforcement theory etc (Talya and Berim, 2010). It was proposed in 2002 by Coens and Jenkins that performance appraisal is necessary in organizations to judge, rate and illustrate employee's work attitude or qualities for a specific time period and results are kept confidential by the organization. Lawrel et al, (1984) discussed that it is current need of the time to keep performance appraisal system at the core of integrated HRM activities.

\section{Problems and Objectives}

Does a promotional opportunity or increase in pay scale lead to higher job satisfaction of employees? Apart from these elements what types of incentives and motivational factors can more effectively promote innovation and increase the employee motivation?

To get insight to overcome the motivational requirements the study tries to explore the factors and incentives should change implemented or eliminated to motivate them. Similarly the study tries to assess the factors that lead to effective job performance, high morale and motivation of the employees of sample unit. 


\section{Data and Methods}

The research design for this study is to assess the motivational factors that can increase employee motivation and promote innovation within BHSS. Therefore, under case study research design descriptive and analytical research strategy has been used in qualitative research approach. The target population for the study consist staff of BHSS working in all areas. The total number of people participating population is about 40. Thus all the employees were given questionnaires and their responses were analyzed. The target organization for the study of employee motivation was an educational organization, located in Kundahar, Pokhara. It is one of the oldest school which was established 35 years ago (2037 BS) and has 40 employees in different departments. This is an old oganization which has diverse work force and nature. Altogether there are near about 150 boarding schools in Kaski district. Majority of them are located in Pokhara valley. BHSS is one of the oldest school, which have sufficient no of teaching and non-teaching staffs. In addition to this it has sufficient no of students also. Thus, BHSS is selected as study unit. The study depends on primary data collected from the staff and some secondary data. The primary data was collected from the field survey using questionnaires and interview schedules. The questionnaires comprised of both close-ended and open-ended questions. These formed the basis of the analysis of the study. The questionnaire and the interview have been done with all the staff of all departments. Both qualitative and quantitative methods of data analysis were used for the study.

\section{Disussion and Analysis}

The previous section addressed the contextual, theoretical and descriptive aspects of the study. The focus of the present chapter is to analyze the field data and examine the findings in the light of the objectives of the study. The quantitative data collected under the survey was coded for the analysis. The quantitative data was also thoroughly discussed in relation to the objectives of the study.

Table1: Gender of respondents

\begin{tabular}{|l|c|c|}
\hline \multicolumn{1}{|c|}{ Composition } & Frequency & Percentage (\%) \\
\hline Male & 18 & 45 \\
\hline Female & 22 & 55 \\
\hline Total & 40 & $100 \%$ \\
\hline
\end{tabular}

Source: Field survey, 2015

Table shows that 18 respondents are male and 22 respondents are female in the organization.

Table 2: Respondent by age

\begin{tabular}{|c|c|c|}
\hline Age & Frequency & Percentage (\%) \\
\hline $20-30$ & 21 & 52.5 \\
\hline
\end{tabular}




\begin{tabular}{|c|c|c|}
\hline $31-40$ & 13 & 32.5 \\
\hline $41-50$ & 4 & 10 \\
\hline Above 50 & 2 & 5 \\
\hline Total & 40 & 100 \\
\hline
\end{tabular}

Source: Field survey, 2015

Table shows that 21 respondents are within the age of 20-30 years, 13 respondents are within the age of 31-40 years 4 respondents are within the age of 41-50 years and 2 respondents are above 50 years.

Table 3: Respondent educational level

\begin{tabular}{|l|c|c|}
\hline \multicolumn{1}{|c|}{ Education } & Frequency & Percentage (\%) \\
\hline Under SLC & 8 & 20 \\
\hline Certificate level & 13 & 32.5 \\
\hline Bachelor & 12 & 30 \\
\hline Master & 7 & 17.5 \\
\hline Total & 40 & 100 \\
\hline
\end{tabular}

Source: Field survey, 2015

Table shows that 8 employees are under SLC, 13 employees have achieved certificate level, 12 employees have bachelor level and 7 employees have master level degree.

Table 4: Respondent by work experience

\begin{tabular}{|l|c|c|}
\hline \multicolumn{1}{|c|}{ Period } & Frequency & Percentage (\%) \\
\hline Less than 1 year & 3 & 7.5 \\
\hline 2-4 year & 20 & 50 \\
\hline 5-7 year & 8 & 20 \\
\hline 8-10 year & 7 & 17.5 \\
\hline Above 10 year & 2 & 5 \\
\hline Total & 40 & 100 \\
\hline
\end{tabular}

Source: Field survey, 2015

Table shows that 20 employees has work experience of 2-4 years, 8 employees has 5-7 years' work experience, 7 employees has 8-10 years' work experience, 3 employees has less than 1 year experience and 2 employees has experience above 10 years. 


\section{Table 5: Most motivating factors}

\begin{tabular}{|l|c|c|}
\hline \multicolumn{1}{|c|}{ Motivating factors } & Frequency & Percentage (\%) \\
\hline Salary & 12 & 30 \\
\hline Good working environment & 15 & 37.5 \\
\hline Freedom to work & 4 & 10 \\
\hline Recognition & 9 & 22.5 \\
\hline Total & 40 & 100 \\
\hline
\end{tabular}

Source: Field survey, 2015

Above table shows that 15 employees consider good working environment as motivating factors, 12 consider salary, 9 consider recognition and 4 consider freedom to work as their motivating factors.

Table 6: Incentives influence performance

\begin{tabular}{|c|c|c|}
\hline Incentives influence performance & Frequency & Percentage (\%) \\
\hline Yes & 30 & 75 \\
\hline No & 10 & 25 \\
\hline Total & 40 & 100 \\
\hline
\end{tabular}

Source: Field survey, 2015

Above table shows that 30 employees think that incentives influence their performance while 10 employees think different.

Table 7: Fair Performance appraisal system

\begin{tabular}{|l|c|c|}
\hline \multicolumn{1}{|c|}{ Response } & Frequency & Percentage (\%) \\
\hline Yes & 26 & 65 \\
\hline No & 14 & 35 \\
\hline Total & 40 & 100 \\
\hline
\end{tabular}

Source: Field survey, 2015

Table shows that 26 respondents find the performance appraisal system fair in BHSS. And 14 respondents find the system not fair for all employees.

Table 8: Satisfaction level with motivation packages

\begin{tabular}{|l|c|c|}
\hline \multicolumn{1}{|c|}{ Level } & Frequency & Percentage (\%) \\
\hline Satisfied & 28 & 70 \\
\hline Average & 12 & 30 \\
\hline Total & 40 & 100 \\
\hline
\end{tabular}

Source: Field survey, 2015 
Above table shows that 28 respondents are satisfied with the motivational packages provided by the organization and 12 respondents are dissatisfied on an average level.

Table 9: Monetary vs. non-monetary incentives

\begin{tabular}{|l|c|c|}
\hline \multicolumn{1}{|c|}{ Incentives } & Frequency & Percentage (\%) \\
\hline Monetary & 14 & 35 \\
\hline Non-monetary & 15 & 37.5 \\
\hline Both & 11 & 27.5 \\
\hline Total & 40 & 100 \\
\hline
\end{tabular}

Source: Field survey, 2015

Table shows that 14 respondent enjoy monetary incentives, 15 respondent enjoy nonmonetary incentives, while 11 respondent feel both monetary and non-monetary incentives are important.

Table 10: Suggested motivational package

\begin{tabular}{|l|c|c|}
\hline \multicolumn{1}{|c|}{ Suggested motivational package } & Frequency & Percentage (\%) \\
\hline Promotion on the basis of experience/performance & 18 & 45 \\
\hline Job related training & 14 & 35 \\
\hline Recognition & 8 & 20 \\
\hline Total & 40 & 100 \\
\hline
\end{tabular}

Source: Field survey, 2015

Table 10 shows that 18 respondent want promotion on the basis of experience/ performance. 14 respondents want job related training and 8 respondent want recognition as motivational package in their organization.

Figure 2: Suggested motivational package

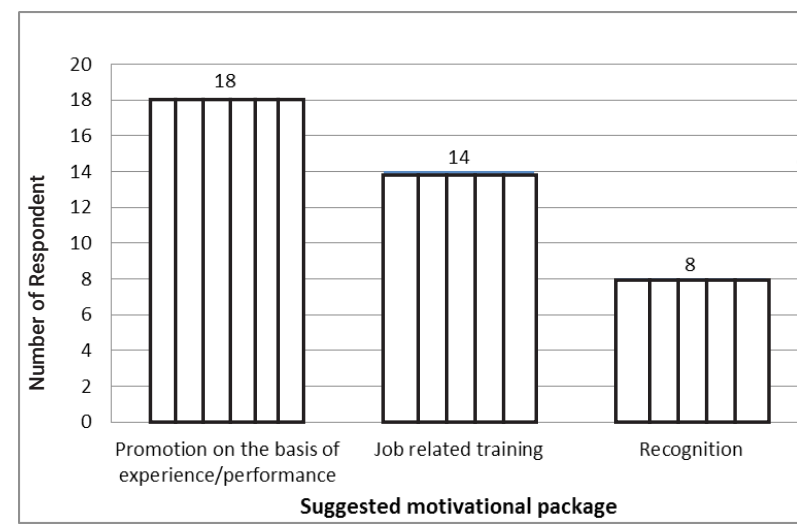


A Study on Employee Motivation in Private School: A Case of Bethany ...

Figure shows $45 \%$ of the respondent want to add promotion on the basis of experience and performance, $35 \%$ respondent wish to have job related training and $20 \%$ respondent want recognition while they give their best on their job.

\section{Results}

From the analysis conducted on previous section 55\% of the workforce covers female staff and $45 \%$ male staff. $52.5 \%$ of the employee's age are between $20-30$ years, $32.5 \%$ respondent are between 31-40 years. It shows majority of the workforce are in productive stage.32.5\% of the respondent has education up to certificate level, 30\% are in bachelor degree, and rest of the percent cover SLC and Master level. Most of the respondent has got good academic knowledge. 50\% of the respondent has 2-4 years' experience, $7.5 \%$ has less than 1 year experience and rest has more than 4 years' experience. This organization use salary, work recognition, allowance and good working environment as motivating factors for employee. $37.5 \%$ of the respondent considers they have good working environment. Salary $(30 \%)$ and recognition $(22.5 \%)$ are other motivating factors. $75 \%$ respondent believes that high incentives influence their performance, while 25\% think different. 65\% respondent considers performance appraisal system is fair in the organization. $70 \%$ respondent says that they are satisfied with the provided motivational packages, rest 30\% in average level. Non-monetary incentives are considered as good motivators by $37.5 \%$ respondent, 35\% considers monetary incentives as motivators and $27.5 \%$ considers both monetary as well as non-monetary incentives are equally important. Respondent has found the promotion system very weak, 45\% respondent wish to add promotion on the basis of experience and performance. 35\% employee want job related training to enrich their ability to perform well. 20\% employees want work recognition, whether they are monetary or non-monetary.

\section{Conclusions}

Above results guided to conclude as workforce comprises of both female and male staff, although majority covers female staff. Most of the employees are in age between 20-30 years. The young generation is attracted to work with this organization. Huge percentage of the employee has achieved good academic qualification. Organization chooses qualified persons to achieve its goal. Organization is not bias on gender matter. Male and female staffs are equally working in all departments. More employees have more than 2 years' work experience. It shows employees enjoy the work and less people have less than 1 year experience. Managing human resource is not easy and it differs individually. To deal different interest, this organization has introduced salary, work recognition, allowance and good working environment as motivating factors. Majority of the employee are motivated because of good working environment. Employees of BHSS consider performance system is fair for all employees working in different depart or areas. Employees consider both monetary and non-monetary incentives are equally important to motivate them. Most of the respondent satisfied with motivational packages and very less are in average level. As a result of the provided motivational packages employee are happy to work with target groups and have got inner satisfaction. In motivational packages, promotion, job related training and work recognition have effects on employee performance. So, employees want to add these in future.

\section{Recommendations}

Based on the findings stated above, the following were the recommendations of the study: 
It is good to have young people in organization; it can create more productivity in programs. People with good academic qualification use them in appropriate field of need. It is good to have more experienced people in organization. So, management is suggested to capitalize this resource in future. Salary is a part of financial rewards for the work of an employee. It is also one of the motivating and stimulating factors. If the wages system is managed well at the organization, it can raise employee motivation productivity. It is quite necessary to make sure that the working environment of the organization is good and does not cause any discomfort for the employees during the work process. At present, majority of the employees are found satisfied, but human motivation is changeable and not stable. It should be considered in mind. Work recognition, promotion and job related training are expected thing from employee. So, it should be considered in future. Not only monetary incentives but also non-monetary incentives should be taken into consideration by the organization. Training is essential for the workers higher productivity or innovation in workplace. Creating a comfortable working environment for the training is one of the issues that the organization should take notice in. Feeling valued is a fundamental emotional need. Employees in all ranks want to feel valued, yet junior staff members look for guidance and good word.

\section{BIBLIOGRAPHY}

Acharya, B. S. (2010). Organizational behavior (2nd ed.). Kathmandu. Asmita Books Publishers and Distributors P. Ltd

Adhikari, D. R. (2010). Organizational behavior (3rd ed.). Kathmandu. Buddha Academic Publishers \& Distributors Pvt. Ltd.

Armstrong, M. (2010). Armstrong's handbook of performance management. Kogan Page Limited.

Aswathappa, K. (2005). Human resource and personnel management. New Delhi. Tata McGra-Hill Publishing Company Limited.

Azoulay, P., Graff Zivin, J., \& Manso G. (2011). Incentives and creativity: evidence from the academic lifesciences. Rand Journal of Economics.

Bolman Lee, G., \& Deal T. E. (2003). Reforming organizations (3rd ed.). USA. Jossey-Bass.

Burton, K. (2012). A study of motivation, how to get your employees moving. Thesis, Indiana University.

Cameron, J (2001). Extrinsic rewards and intrinsic motivation in education: Reconsidered once again. Review of Educational Research, vol71.

Cascio, W. F. (2007). Managing human resources: productivity, quality of work, life, profits. (7th ed.). New Delhi. Tata-McGra Hill Publishing Company Limited.

Decenzo, D. A., \& Robbins, S. P. (2005). Fundamentals of human resource management. John Wiley and Sons Inc.

Griffin, R. W. (2000). Management (5th ed.). Delhi. AITBS Publisher and Distributors.

Head, G. M., \& Griffin, R. W. (2009). Managing people and organizations. Delhi. Biztantra 
Khadka S. (2011). Employee retention in banking industry of nepal. Rajasthan, India. Singhania University.

Miner, J. B. (2006). Essential theories of motivation and leadership. New Delhi. Prentice Hall of India Private Limited.

Owusu, T. (2012). Effects of motivation on employee performance: a case study of ghana commercial bank. Thesis, Kumashizone

Salanova, A., \& Kirmen, S. (2010). Employee satisfaction and work motivation. Thesis. Mikkeli University of Applied Sciences.

William, A. N. (2010). Employee motivation and performance. Thesis. Mikkeli University of Applied Sciences. 